\title{
A comparative study of Transit Oriented Development (TOD) at Yogyakarta Railway Station
}

\author{
Okkie Putriani ${ }^{1, *}$, and Ibnu Fauzi $^{1}$ \\ ${ }^{1}$ Universitas Atma Jaya, Transportation Graduate Program, Civil Engineering, Yogyakarta, Indonesia
}

\begin{abstract}
Optimizing the public transport and synergizing the land use can reduce the impact of urban development by attracting the development around the transit station. This situation encourages the accessibility of public transportation by creating conditions between passenger expectations realted to the concept Transit Oriented Development (TOD) between land use, mobility, and environment. This study was conducted by TOD with the area located in the center of local wisdom by cultural city, Yogyakarta Railway Station. The purpose of this study is to provide an alternative location where bus stops or Trans Jogja shelters are more easily accessible by users of rail services and facilitate the model's transfer. The method of this research is descriptive quantitative. It explains the trans it function, needs and condition of Trans Jogja as the existing public transport and the accessibility of the bus stops. The conclusion is the recommendation for the bus stop location can be relocate near the dropout East and South area of the Railway Station
\end{abstract}

\section{Introduction}

A future-oriented city, which has a big role in the transport sector, must be sustainable. The transportation sector should be able to provide convenience for all communities in all activities [1]. Total population of DIY in 2015 was recorded 3,679,179 with population growth in 2010 reached 1.19 percent. The total area of $3,185.80 \mathrm{~km}^{2}$, the population density in DIY based on Central Bureau of Statistics (BPS) data reaches 1,115 people per $\mathrm{km}^{2}$ with the highest density occurring in Yogyakarta city which is 12,699 people per $\mathrm{km}^{2}$. Yogyakarta as the tourism city, culture and a center of education with the number of students scattered 116 colleges of 184,328 students and 10,833 teachers. Urban expansion (urban sprawl) and poor land use planning contribute greatly to traffic congestion, air pollution and greenhouse gas emissions [2]. Public transportation can reduce the impact of division by attracting the development around the transit station and this development also supports public transportation by creating conditions that can meet passenger expectations with the concept of transportation development in synergy with the spatial to strengthen the environment or known as Transit Oriented Development (TOD). Tugu Yogyakarta Railway Station, based on data of PT. Kereta Api Indonesia (Persero) throughout 2016 Yogyakarta

\footnotetext{
*Corresponding author: okkieandfriends@gmail.com
} 
Station serves 5,213,767 passengers with the composition of $44 \%$ passengers from Yogyakarta Station and $56 \%$ of passengers Yogyakarta destinations served by 52 trains every day is located at the center of Yogyakarta City. These condition shows the needs of a comparative study of TOD area in Yogyakarta Station as one of the transportation system nodes and the catalyst of economic activity of Special District of Yogyakarta.

\section{Literature review}

\subsection{Transit Oriented Development (TOD)}

The concept of Transit Oriented Development (TOD) is significant way of improving the effectiveness of transit as well as supporting community goals and improving accessibility $[3,4]$. It begins with the concept of human movement activity, either by vehicle or walking. Movement as one of the most widely performed activities by humans, is accommodated by the placement of activity centers integrated with transit points, so it is expected to encourage the use of public transportation. Activity centers are connected to each other in convenient and recommended walking distance in an effort to reduce intermodal shifts [5]. According to the Center for Land Transportation and Railways [6] sustainable transportation is a transportation that encourages the use of environmentally friendly technologies to meet the needs of the community. One effort that can be done is to use the concept of TOD to reduce population mobility among urban areas through an integrated system of development. TOD should be placed:

1. On the main network of mass transit.

2. In high-frequency bus / BRT bus corridors

3. In the bus feeder network that takes less than 10 minutes from the main network of mass transit

If the above requirements are not met by a region then it is necessary to take steps to connect with mass transit, besides that also need to be considered is the high frequency of public transport. The Urban Land Istitute, America, ten principles for successful development around transit [7]:

1. Make it better with a vision

2. Apply the power of partnerships

3. Think development when thinking about transit

4. Get the parking right

5. Build a place, not a project

6. Make retail development market driven, not transit driven

7. Mix uses, but not necessarily in the same place

8. Make buses a great idea

9. Encourage every price point to live around transit

10. Engage corporate attention

\subsection{Local Wisdom: Cultural Aspects}

The concept of culture city was formed by the King of Yogyakarta Hamengku Buwono I based on social concept, state and functional. The concept manifested in the structure, the pattern of space, and the image of the city: Catur Sagotra (Catur Gotro Tunggal) microcosm and macrocosm in one living space. The concept of the city is connected by the road space, from the functions of government, religion, economy, and culture. The concept was described by Figure1 of Golig Gilig, the intention of uniting all groups. Cultural 
concept of Memayu Hayuning Bawono, Manunggaling Kawulo Gusti, Sangkan Paraning Dumadi, and Pathok Negoro.

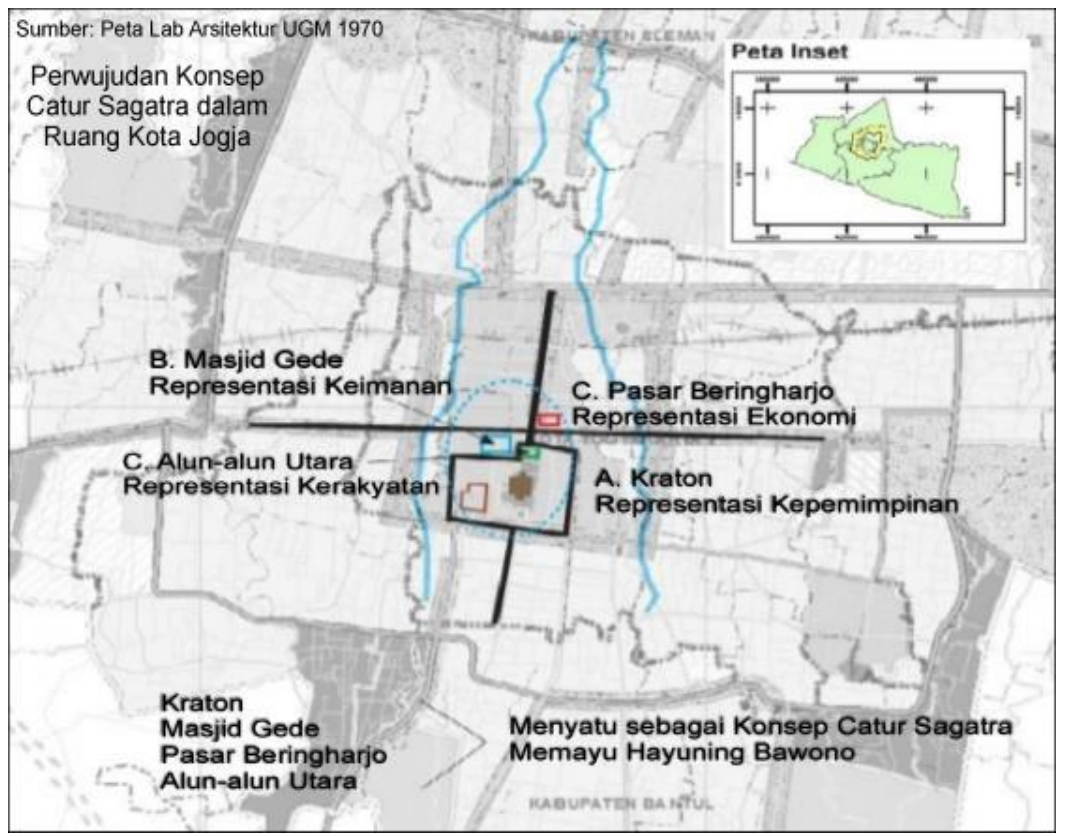

Fig. 1. Cultural Aspects of Yogyakarta City (Source: Map of Architecture Lab UGM, 1970)

\subsection{Railway station}

A railway station is a place at which passenger join or leave trains. It is a place of arrival and departure, for trains as well as passengers, two diverse units, causing a railway station to fall into two distinct parts: the passenger concourse and the train shed, to each of which a different measure must be applied if they are to be apt and fit for their purpose [8]. According to Indonesia Regulation Ministry of Transportation [9], types, classes and activities at railway station, there are 6 (six) criteria for classifying stations into large stations, medium stations, or small stations, namely operating facilities, number of lanes, passenger facilities, rail traffic frequency, daily passenger number, and daily amount of goods.

\subsection{Bus stop}

Based on the decision of the Director General of Land Transportation [10] about bus stop design standards and guidelines, bus stops are a critical part of the transit system as they serve as the first point of contact between the customer and the services. Bus stop placement throughout the community acts to promote alternative modes of transportation to the public traveling. The space, location, and design all affect the operation of the transit system, in turn, the transit patron's satisfaction. The distances between bus stops are technically different from the terms of land use, for the city center is placed at a distance of 300 to $500 \mathrm{~m}$ and in the suburbs between 500 and $1000 \mathrm{~m}$. 


\subsection{Parking}

The Republic of Indonesia constitution [11] about road traffic, 1st article 15th paragraph, porary vehicle because it is abandoned by the driver. In the technical guidance of the Directorate General of Land Transportation facility [12], parking is based on its layout known as on-street parking and off street parking, explained by table 1 .

Table 1. General Space Requirements, Type of Vehicle and Area of Parking Space

\begin{tabular}{llc}
\hline No & Type of Vehicle & Area of Parking Space $\left(\mathbf{m}^{2}\right)$ \\
\hline 1.a. & Passenger Car, I classes & $2.30 \times 5.00$ \\
\hline 1.b. & Passenger Car, II classes & $2.50 \times 5.00$ \\
\hline 1.c. & Passenger Car, III classes & $3.00 \times 5.00$ \\
\hline A. & Bus / truck & $3.40 \times 12.50$ \\
\hline B. & Motorcycle & $0.75 \times 2.00$ \\
\hline Source: General Directorate of Land Transportation
\end{tabular}

\subsection{Mode choice}

In urban travel demand modeling, from individual choices to general equilibrium, Oppenheim [13] stated that the main modes of transport and urban form are private vehicles, public transport (including buses and trains), including "paratransit" (taxis and others), walking and cycling. Warpani [14] stated that in some places two-wheeled vehicles are used as public vehicles (motorcycles) with free passes such as taxis. Therefore, twowheeled vehicles can not be ignored in the loading of road network in Indonesia.

\subsection{Intermodal Concept in Railway Station Design}

Kandee [15] explained applying the intermodal concept in rail services heralds a number of developments, one of which is the role of railway stations. The increasing numbers of passengers has resulted in the need for modern and rational designs of station. The intermodal concepts supports the integration of related transportation modes.

\section{Methodology}

These descriptive research is trying to describe symptoms, events, and occurrence happenings. This research is using qualitative research method. Creswell at Noor [16] qualitative research is a descriptive analysis, the theoretical basis used as a guide to focus the research according to the fact in the field. The flow of the research stages in this study is shown in Figure 2.
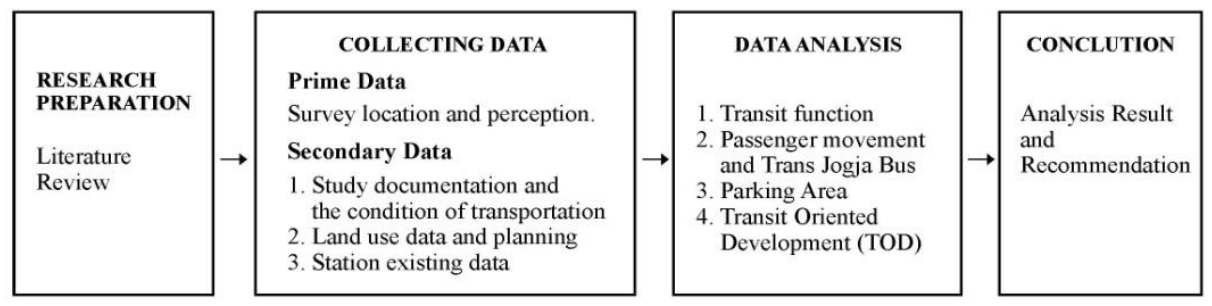

Fig. 2. Research Flowchart 


\section{Result}

\subsection{The Characteristic of Yogyakarta Railway Station (YRS)}

Yogyakarta Railway Station (YRS), known as Tugu Station, is located in the center of Yogyakarta Special Region City and it is under auspices of PT Kereta Api Indonesia Region VI Yogyakarta (DAOP 6). This station showed in Figure 3 serves the departure and arrival of an executive and business class train (KA). YRS is the largest railway station in the province of Yogyakarta Special Region. This station belongs to a large class station with six main lines. In addition, in the station emplacement area there is a locomotive and railroad locomotive in the north and west of the station complex.

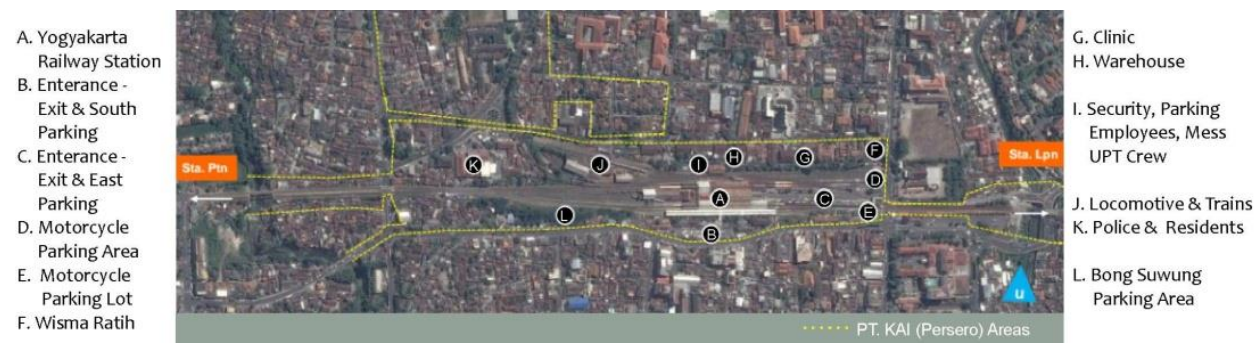

Fig. 3. Existing Area Yogyakarta Railway Station (Source : Unit Maintenance, Preservation \& Architecture PT. Kereta Api Indonesia (Persero), 2016)

The station has two entrances and exits, the main entrance facing J1. Margo Utomo (Jl.P. Mangkubumi, including Gowongan Urban Village, Jetis Sub-district) and the south entrance facing towards J1. Pasar Kembang (Sosromenduran, Gedongtengen Sub-district).

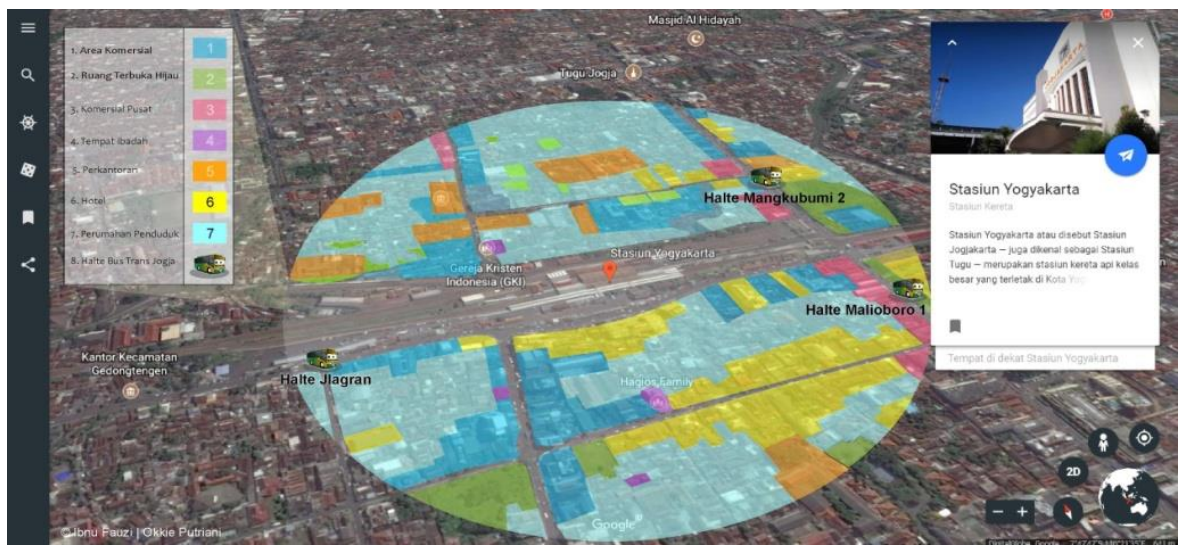

Fig. 4. Land Use of Yogyakarta Railway Station (Source: Google Earth and Survey Analysis)

\subsection{Land Use of Yogyakarta Railway Station}

Based on the surrounding Yogyakarta railway station Figure 4, the land use area are dominated by residential (light blue), hotel (yellow), office (orange), commercial area (blue), commercial center (pink), green open space, and Trans Jogja bus stop. A city plan should not only focus on area within its administrative boundaries, because urban lands are always expanding parallel with the growth of its population and activities. 


\subsection{Transit}

According to Calthorpe [17], and Mirmoghtadaee [18] the transit function in the TOD region serves as a place of transit activity located to the main transit city movement network. The research area of YRS has been integrated with the main transit city movement network, Trans Jogja Bus. The accessibility to get the bus stop for the pedestrians is still very low. This can be seen in the following Figure 5 the location of Trans Jogja bus stop near Yogyakarta Railway Station.

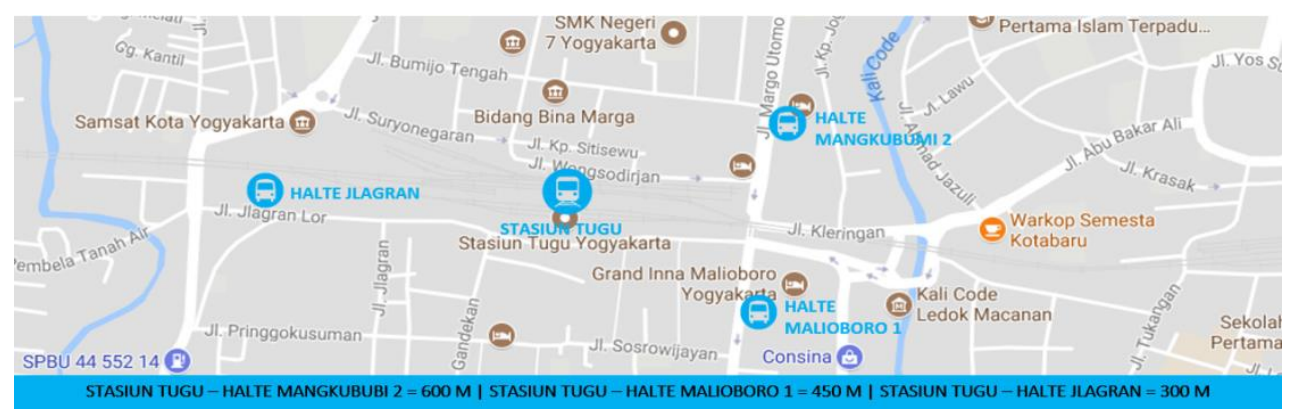

Fig. 5. The Location of Trans Jogja Bus Stop Near Yogyakarta Railway Station

The movement pattern of the passengers at Yogyakarta Railway Station obtained from the results of a questionnaire tabulated to 100 respondents Train users in Tugu Station, presented in Table 2 below:

Table 2. Tabulation Questionnaire

\begin{tabular}{|c|c|}
\hline Residence & $40.7 \%$ Sleman; $31.1 \%$ Jogja City; $21.4 \%$ others; $6.8 \%$ Bantul \\
\hline Gender & $53.4 \%$ Male; $46.6 \%$ Female \\
\hline Age & $73.8 \% 17-25 ; 23.3 \% 26-35 ; 1.9 \% 36-45 ; 1 \% 46-55$ \\
\hline Occupation & $\begin{array}{l}60.2 \% \text { Univ. students; } 21.4 \% \text { Employees; } 5.8 \% \text { Entrepre } \\
\text { neurs; } 4.9 \% \text { PNS; } 1.9 \% \text { Housewifes; } 5.8 \% \text { others }\end{array}$ \\
\hline Destination & $\begin{array}{l}40.8 \% \text { Jkt; } 12.6 \% \text { Solo; } 11.7 \% \text { Bdg; } 10.7 \% \text { Sby; } \\
3.9 \% \text { Purwokerto; } 2.9 \% \text { Cirebon; } 2,9 \% \text { Kediri; } 10.6 \% \text { Others }\end{array}$ \\
\hline Accessibility to Railway Station & $\begin{array}{l}\text { 42.7\% Easy; } 19.4 \% \text { Quite Easy; } 14.6 \% \text { Quite Difficult; } \\
\text { 3.9\% Very Difficult; } 1.9 \% \text { Difficult }\end{array}$ \\
\hline Mode to Railway Station & $\begin{array}{l}\text { 46.6\% Motorbike; } 24.3 \% \text { Rental; } 14.6 \% \text { Private Cars; } \\
7.8 \% \text { Taxi, } 1.9 \% \text { Trans Jogja Bus; } 5 \% \text { Others }\end{array}$ \\
\hline Mode from Railway Station & $\begin{array}{l}40.8 \% \text { Motorbike; } 32 \% \text { Rental; } 18.4 \% \text { Private Cars; } \\
1.9 \% \text { Taxi; } 1.9 \% \text { Trans Jogja; } 5 \% \text { others }\end{array}$ \\
\hline $\begin{array}{l}\text { Convenience of Obtaining Public Transport } \\
\text { from Railway Station }\end{array}$ & $\begin{array}{l}35 \% \text { Easyl } 26.2 \% \text { Quite Difficult; } 15.5 \% \text { Quite Easy, } \\
10.7 \% \text { Difficult; } 9.7 \% \text { Very Difficult; } 2.9 \% \text { Very Easy }\end{array}$ \\
\hline Travel Destination & $\begin{array}{l}33 \% \text { Recreation; } 24.3 \% \text { Visiting Relatives; } 22.3 \% \text { Edu- } \\
\text { cation; } 15 / 5 \% \text { Business; } 4.9 \% \text { others }\end{array}$ \\
\hline Travel Time & $\begin{array}{l}58.3 \% 15-31 \mathrm{~min} ; 18.4 \% 31-45 \mathrm{~min} ; 11.7 \%<15 \mathrm{~min} \\
4.9 \%>75 \mathrm{~min} ; 3.9 \% 61-75 \mathrm{~min} ; 2.9 \% 46-60 \mathrm{~min}\end{array}$ \\
\hline Railway Station Distance From Residence & $\begin{array}{l}31.1 \% 3.1-6 \mathrm{~km} ; 28.2 \% 6.1-9 \mathrm{~km} ; 12.6 \% 9.1-12 \mathrm{~km} ; \\
10.7 \% 12.1-15 \mathrm{~km} ; 10.71-3 \mathrm{~km} ; 6.8 \%>15 \mathrm{~km}\end{array}$ \\
\hline Punctuation of Train Schedule & $95.1 \%$ on-time; $4.9 \%$ not on-time \\
\hline Pedestrian Accessibility & $52.4 \%$ not yet; $32 \%$ yet; $15.5 \%$ not know \\
\hline Optional Mode of Transportation & 78.6\% Rental; $13.6 \%$ Taxy; $7.8 \%$ TransJogja Bus \\
\hline
\end{tabular}

Based on the TOD strategies, the area should be reduced motor vehicles users and maximize walking of the pedestrian. From Table 1 showed $61 \%$ of respondents still use 
private vehicles to get to the station, and $52 \%$ of respondents used vehicles to leave the station.

\subsection{Trans Jogja Bus}

The data obtained from the Transportation Department of the Special Province of Yogyakarta is the number of Transjogja buses in 2017 as many as 105 buses serving 15 routes / lines are $1 \mathrm{~A}, 1 \mathrm{~B}, 2 \mathrm{~A}, 2 \mathrm{~B}, 3 \mathrm{~B}, 6 \mathrm{~B}, 4 \mathrm{~B}, 5 \mathrm{~A}, 5 \mathrm{~B}, 6 \mathrm{~A}, 6 \mathrm{~B}, 7,8,9,10$ and 11. The capacity of one Transjogja bus unit is 41 passengers divided into 22 seated passengers and 19 passengers standing. Trans Jogja operational hours start at 05:30 WIB - 21:30 WIB.

\subsection{People Movement and Trans Jogja Bus}

\subsubsection{Demand}

The obtaining movement data analysis of PT. Kereta Api Indonesia (Persero) resulted:

Table 3. The Movement of Yogyakarta Station People

\begin{tabular}{|c|c|c|c|c|c|}
\hline \multicolumn{2}{|c|}{$\frac{\text { Activities }}{\text { People Mobility }^{*}}$} & \multicolumn{2}{|c|}{ Monthly Average } & \multicolumn{2}{|c|}{$\begin{array}{l}\text { Average Per } 15 \text { minutes } \\
\text { In Rush Hours }\end{array}$} \\
\hline In & Out & In & Out & In & Out \\
\hline $1,297,856$ & $1,595,380$ & 216,309 & 265,897 & 165 & 186 \\
\hline
\end{tabular}

The activity data of people moving in and out of Yogyakarta Station last six months, where the number of people entering either will go by train, pick up, and other necessities as much as 165 people in 15 minutes. As for the number of people coming out of the station an average of 186 people are out of the station within 15 minutes.

\subsubsection{Trans Jogja Circulation}

The result of data survey for 4 hours starting at 12:00 pm - 16:00 pm at two bus stops nearest Yogyakarta obtained the following data:

Table 4. Circulation of Trans Jogja Around Yogyakarta Station per 15 Minutes

\begin{tabular}{|c|c|c|c|c|c|c|c|}
\hline \multirow{2}{*}{\multicolumn{2}{|c|}{ TIME }} & \multicolumn{3}{|c|}{ MANGKUBUMI BUS STOP 2} & \multicolumn{3}{|c|}{ JLAGRAN BUS STOP } \\
\hline & & \multirow{2}{*}{$\begin{array}{c}\text { LINE 1A } \\
1\end{array}$} & \multirow{2}{*}{$\begin{array}{c}\text { LINE 2 A } \\
1\end{array}$} & \multirow{2}{*}{$\frac{\text { TOTAL }}{2}$} & \multirow{2}{*}{$\begin{array}{c}\text { LINE 3A } \\
1\end{array}$} & \multirow{2}{*}{$\begin{array}{c}\text { LINE } 8 \\
0\end{array}$} & \multirow{2}{*}{$\begin{array}{c}\text { TOTAL } \\
1\end{array}$} \\
\hline $12: 00$ & $12: 15$ & & & & & & \\
\hline $12: 16$ & - $12: 30$ & 2 & 0 & 2 & 0 & 1 & 1 \\
\hline $12: 31$ & $12: 45$ & 1 & 1 & 2 & 1 & 0 & 1 \\
\hline $12: 46$ & - $13: 00$ & 1 & 1 & 2 & 1 & 1 & 2 \\
\hline 13:01 & $-13: 15$ & 2 & 1 & 3 & 0 & 0 & 0 \\
\hline $13: 16$ & - $13: 30$ & 3 & 1 & 4 & 1 & 0 & 1 \\
\hline $13: 31$ & $13: 45$ & 1 & 1 & 2 & 1 & 1 & 2 \\
\hline $14: 46$ & $-14: 00$ & 1 & 1 & 2 & 1 & 0 & 1 \\
\hline $14: 01$ & - $14: 15$ & 1 & 1 & 2 & 0 & 0 & 0 \\
\hline $14: 16$ & - $14: 30$ & 2 & 1 & 2 & 1 & 1 & 2 \\
\hline $14: 31$ & - $14: 45$ & 1 & 1 & 3 & 0 & 0 & 0 \\
\hline 14.46 & - $15: 00$ & 1 & 1 & 2 & 1 & 0 & 1 \\
\hline $15: 01$ & - $\quad 15: 15$ & 1 & 2 & 2 & 1 & 1 & 2 \\
\hline $15: 16$ & - $15: 30$ & 2 & 1 & 3 & 1 & 0 & 1 \\
\hline $15: 31$ & - $15: 45$ & 2 & 1 & 3 & 0 & 1 & 1 \\
\hline 15.46 & $\begin{array}{l}-\quad 16: 00 \\
\end{array}$ & 2 & 1 & 3 & 1 & 0 & 1 \\
\hline \multicolumn{2}{|c|}{ TOTAL } & 24 & 16 & 40 & 11 & 6 & 17 \\
\hline
\end{tabular}


The number of Trans Jogja passing through J1. Margoutomo (Mangkubumi 2 ) bus stop within 4 hours were 40 buses. Trans Jogja passes J. Jlagran Pasar Kembang bus stopo was 17 buses.

\subsubsection{Public Transport Needs (Trans Jogja)}

To calculate the number of additional Trans Jogja buses required can be done by calculating the number of additional buses based on the number of rit and the number of bus travel:

Note :

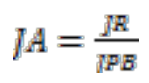

$J A:$ number or buses (1)

$J P B:$ number of bus trips (rit/day)

$J R:$ number of rit (rit/day)

$W P$ : travel time (minutes)

$$
\begin{gathered}
W P=\frac{\text { Rate Distance }}{\text { Speed of Plan }} \times 60 \text { minutes } \\
I P B=\frac{\text { Operation Time }}{\text { Travel Time }} \times 60
\end{gathered}
$$

Table 5. Calculation of Additional Unit

\begin{tabular}{lcccccc}
\hline Trans Jogja & $\begin{array}{c}\text { Distance } \\
\text { Rute }(\mathbf{k m})\end{array}$ & $\begin{array}{c}\text { Average } \\
\text { Speed }(\mathbf{k m} / \mathbf{h o u r})\end{array}$ & JR & $\begin{array}{c}\text { WP } \\
\text { (2) }\end{array}$ & $\begin{array}{c}\text { JPB } \\
\text { (3) }\end{array}$ & $\begin{array}{c}\text { JA } \\
\text { (1) }\end{array}$ \\
\hline Line 1A & 34.7 & 40 & 96 & 52 & 18 & 5 \\
\hline Line 2A & 32.1 & 40 & 64 & 48 & 20 & 3 \\
\hline Line 3A & 37.6 & 40 & 44 & 56 & 17 & 3 \\
\hline Line 8 & 25.5 & 40 & 24 & 38 & 25 & 1 \\
\hline
\end{tabular}

Based on the calculation, it was shown that the ideal journey time of Trans Jogja route $1 \mathrm{~A}$ in one rit was 52 minutes. The number of trip bus journey $1 \mathrm{~A}$ was $18 \mathrm{rit} / \mathrm{day}$, then the addition of the number of Trans Jogja buses to accommodate the potential demand is 5, route $2 \mathrm{~A}$ and $3 \mathrm{~A}$ each 3 and route 8 is 1 Trans Jogja bus.

\subsection{Condition of Existing Parking and Parking Plans at Yogyakarta Station}

Parking violation is happen in the sidewalk of the station. Parking without a zone permit is because of the ignorance. East side parking area Bong Suwungwas divided into 2,844 $\mathrm{m}^{2}$ for cars, $844 \mathrm{~m}^{2}$ for motorcycle and $846 \mathrm{~m}^{2}$ for motor stay. Meanwhile the parking area on the south side was divided into $1060 \mathrm{~m}^{2}$ for the car and $687 \mathrm{~m}^{2}$ for the motor. Existing conditions for the capacity of the car park east side Tugu Station amounted to 107 vehicles. East motorcycle parking capacity was 302 motorcycles. Motorway parking on the east side of Tugu Station can accommodate 271 motorcycles. Car parking capacity south of Tugu Station was 39 vehicles. Motor parking on the south side accommodated 264 motors.

To maximize the concept of TOD at Yogyakarta Tugu Railway Station, there are two alternatives in planning of parking capacity arrangement at Tugu Railway Station Yogyakarta.

1. Parking capacity at Tugu Station with the least capacity. The advantages of this alternative are:

a. Parking access becomes more widespread so that the circulation in and out of the vehicle more smoothly.

b. Users of private vehicles using parking at Tugu station switch using Transjogja mode. This arrangement can be done if it has been supported by the availability of Transjogja in fulfilling the existing demand and change of location of Transjogja 
shelter closer to Tugu Station so that vehicle users are interested to switch modes to

Transjogja.

c. Private vehicle users can reduce the increasingly limited consumption of fuel oil.

d. Reduce air pollution around Tugu Station Yogyakarta area.

2. The parking capacity at Tugu Station is maximized. The advantages of this alternative are the capacity of private vehicles parking at Tugu Station can be more optimal and parking arrangements in the Tugu Railway area are more organized. The negative effects of these alternatives are the alternative planning may lead to more people using private vehicles in the region, the number of private vehicle use, the load of roads around Tugu Station area is getting bigger, and increasing air pollution in Tugu Station area.

\subsection{Transit Oriented Development (TOD)}

The concept of TOD should synergize between train, pedestrian, and public transportation (Transjogja). The Transjogja connection is the need for integration in the mode transfer of trains and feeders. This require good public transport services. Transjogja should be able to accommodate the existing demands of the region, close to Tugu Station, and ease to reach the location of stops. It can be made near the dropout hall of Yogyakarja Railway Station on Jalan Mangkubumi and near entrance of Yogyakarta Station Jalan Pasar Kembang.

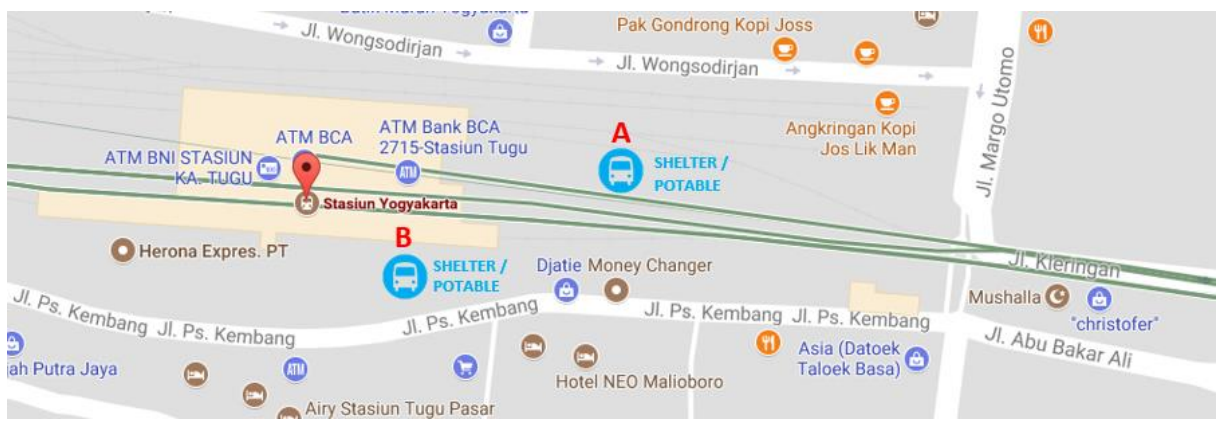

Fig. 6. The Relocation Plan of Trans Jogja Bus Stop (Source: Google Map)

The placement of the new halt plan is intended so that routes $1 \mathrm{~A}$ and $2 \mathrm{~A}$ can be served at bus stop $\mathrm{A} \pm 100 \mathrm{~m}$ from the entrance of YRS hall, while the $3 \mathrm{~A}$ and 8 routes can be served at bus stop $\pm 50 \mathrm{~m}$ from the entrance of East hall. The plan will make easier for passengers to access it. They can continue walking in the pedestrian area that has been provided without having to walk too far. The adjustment of punctual time the arrival and departure schedule of trains with Trans Jogja bus needs to be arranged, so that during rush hours in Yogyakarta Station all potential demand can be covered by the existing Trans Jogja.

\section{Conclusion}

The number of passengers who entering the YTSwith any transportation were 165 people in 15 minutes. The number of people who coming out of the station were 186 people in 15 minutes. In order to accommodate the potential of demand, it is necessary to increase the number of Trans Jogja for 1A 5 units, 2A 3 line, 2A 3 line and make bus stop near Yogyakarta Station. The location can be made near the dropout hall of Yogyakarta Railway Station on Jalan Mangkubumi and near entrance of Yogyakarta Station Jl. Pasar Kembang. The placement of the new halt plan is intended so that routes $1 \mathrm{~A}$ and $2 \mathrm{~A}$ can be served at 
bus stop A which is $\pm 100 \mathrm{~m}$ from the entrance hall of Yogyakarta Station, while the 3A and 8 routes can be served at bus stop $\pm 50 \mathrm{~m}$ from Yogyakarta Station hall entrance East. TOD in the railway station can optimize if there is continuity between the modes either train, private vehicle and public transportation (Trans Jogja). Therefore, two parking regulation alternatives are provided by increasing the parking capacity to make it easier for private vehicle users who are around Yogyakarta Station to move the modes and by minimizing the parking capacity so that the use of private vehicles in the area of Yogyakarta Station will use Trans Jogja.

\section{References}

1. Kusbiantoro, BS. Memanusiakan Perencanaan Sistim Transportasi. Kelompok Keahlian Sistem Infrastruktur Wilayah dan Kota. Bandung: ITB (2007).

2. Vincent G and Harja D. Spatially Explicit Individual-based Forest Simulator (SexI- FS). World Agroforestri Centre (ICRAF) and Institut de Recherche pour le Developpement (IRD). Bogor (2008).

3. Cervero, R., et al., Transit-oriented development in the United States: Experiences, challenges, and prospects. TCRP Report 102. Transportation Research Board.

4. Arief, A. B., Yudono, A., Akil, A., \& Ramli, I. Model of Coastal Transit Oriented Development (TOD) Based on the Potential of Local Port and marine Tourism Port, Case Study: Fort Rotterdam Makassar and the Surrounding Areas. In IOP Conference Series: Earth and Environmental Science (Vol. 79). https://doi.org/10.1088/17551315/79/1/012034. (2017).

5. Wijaya, Alfred. 2009. Penataan Ruang Yang Ramah Lingkungan Melalui Perencanaan TOD (Transit Oriented Development). Seminar Nasional Perencanaan Wilayah dan Kota ITS. Surabaya.

6. Puslitbang Perhubungan Darat dan Perkeretaapian, Study Transit Oriented Development (TOD) Around Tugu Station Yogyakarta, Jakarta (2014).

7. Dunphy R., Myerson D., Pawlukiewicz M.. Ten Principles For Successful Development Around Transit. The Urban Land Insititute, Bank of America. Washington, D.C. ULI. http://uli.org/wp-content/uploads/2012/07/TP_DevTransit.ashx_.pdf last accessed July 30th, 2017 11.07 PM (2003).

8. Pick, Frank. The Design of Modern Railway Stations in Europe and America. Journal of the Royal Institute of British Architects, Vol 37, Third Series, No 10, pages 319 to 332 (1930).

9. Republik Indonesia. Peraturan Menteri Perhubungan Nomor 33 tahun 2011 tentang Persyaratan Jenis, Kelas, dan Kegiatan di Stasiun Kereta Api. Jakarta.

10. Republik Indonesia. Keputusan Direktur Jenderal Perhubungan Darat Nomor : 271/HK.105/DRJD/96 Tentang Pedoman Teknis Perekayasanaan Tempat Perhentian Kendaraan Penumpang Umum. Jakarta.

11. Republik Indonesia. Undang-undang Republik Indonesia Nomor 22 Tahun 2009 tentang Lalu Lintas Angkutan Jalan. Jakarta. 
12. Republik Indonesia. Keputusan Direktur Jenderal Perhubungan Darat Nomor 272 Tahun 1996 tentang Pedoman Teknis Penyelenggaraan Fasilitas Parkir. Jakarta.

13. Oppenheim, N. Urban Travel Demand Modeling, Wiley, New York (1995).

14. Warpani, S, Pengelolaan Lalu Lintas dan Angkutan Jalan. Bandung: ITB. (2002)

15. Kandee and Kandee, Kandee, Kandee, S. 2001. Intermodal Concept in Railway Station Designwww.bu.ac.th/knowledgecenter/epaper/jan_june2004/somruedee.pdf last accessed July 31th, 2017 12.26 AM (2004).

16. Noor, Juliansyah. Metodologi Penelitian : Skripsi, Tesis, Disertasi dan Karya Ilmiah. Kharisma Putra Utama, Jakarta (2011).

17. Calthorpe, P.. The Next American Metropolis: Ecology, Community, and the American Dreams, Princeton Architectural Press, New York (1993).

18. Mirmoghtadaee, M. Challenges of Transit Oriented Development (TOD) in Iran, The Need For A Paradigm Shift. TeMA Journal of Land Use, Mobility, and Environment, special issue, no. 3, pp. 35 - 46 (2016). 